\title{
Pengaruh Rasio Kinerja Bank Terhadap Profitabilitas Industri Bank Umum Syariah di Indonesia
}

\author{
${ }^{1 *}$ Felix Efendy, ${ }^{2}$ Salman Fathoni \\ ${ }^{1,2}$ Magister Ilmu Ekonomi Studi Pembangunan, Universitas Diponegoro, Indonesia \\ *Email korenpondensi: efendy.felix @gmail.com
}

\begin{abstract}
The purpose of this study was to determine and analyze the effect of the level of bank health ratios measured by BOPO, FDR and NPF on increasing the profitability of the Sharia Commercial Bank industry in Indonesia, which is proxied by ROA. The data used in this study are secondary data including operational efficiency (BOPO), liquidity (FDR), Non Performing Finance (NPF) and Return On Assets (ROA) in the sharia commercial bank industry registered at Bank Indonesia. The data is a monthly time series data from 2015-2018 obtained through the official sharia banking statistics website, Financial Services Authority (https://www.ojk.go.id). To analyze it, researchers used a multiple linear regression model with statistical tool software EViews 9. From the observations and analysis of the data that has been done, the conclusions in this study are the BOPO, FDR and NPF on $R O A$ which is an indicator of the Bank's health to measure profitability has a high relationship. The $B O P O$ variable partially has a significant negative effect on profitability (ROA). FDR partially has a negative and significant effect on ROA. NPF partially has no positive effect on profitability.
\end{abstract}

Keywords: BOPO; liquidity (FDR); Non Performing Finance (NPF); Return On Assets (ROA); Islamic Bank Industry

\begin{abstract}
Abstrak
Tujuan penelitian ini adalah untuk mengetahui dan menganalisis pengaruh tingkat rasio kesehatan bank yang diukur dengan BOPO, FDR dan NPF terhadap peningkatan profitabilitas industri Bank Umum Syariah di Indonesia yang diproksikan dengan ROA. Data yang dipakai dalam penelitian ini adalah data sekunder antara lain efisiensi operasional (BOPO), likuiditas (FDR), Non Performing Finance (NPF) dan Return On Asset (ROA) pada industri bank umum syariah yang terdaftar di Bank Indonesia. Data tersebut merupakan data time series bulanan dari tahun 2015-2018 yang diperoleh melalui situs resmi statistik perbankan syariah, Otoritas Jasa Keuangan (https://www.ojk.go.id). Untuk menganalisisnya, peneliti menggunakan model regresi linear berganda dengan software alat statistik EViews 9. Dari hasil pengamatan dan analisis data yang telah dilakukan, simpulan pada penelitian ini adalah BOPO, FDR dan NPF terhadap ROA yang merupakan indikator kesehatan Bank untuk mengukur profitabilitas memiliki hubungan yang tinggi. Variabel BOPO secara parsial berpengaruh negatif signifikan terhadap profitabilitas (ROA). FDR secara parsial berpengaruh negatif dan signifikan terhadap ROA. NPF secara parsial tidak berpengaruh positif terhadap profitabilitas.
\end{abstract}

Kata kunci: BOPO, FDR, NPF, ROA, Industri Bank Umum Syariah

Saran sitasi: Efendy, F., \& Fathoni S. (2019). Pengaruh Rasio Kinerja Bank Terhadap Profitabilitas Industri Bank Umum Syariah di Indonesia. Jurnal Ilmiah Ekonomi Islam, 5(03), 217-224. doi: http://dx.doi.org/10.29040/jiei.v5i3.655

DOI: http://dx.doi.org/10.29040/jiei.v5i3.655 


\section{Pendahuluan}

Berdasarkan fungsinya perbankan yang beroperasi di Indonesia terbagi menjadi tiga macam, yaitu Bank Sentral, Bank Umum dan Bank Pengkreditan Rakyat. Sesuai dengan pasal 5 Undang-Undang Nomor 10 Tahun 1998, tentang Perbankan terdapat dua jenis bank, yaitu Bank Umum dan Bank Perkreditan Rakyat. Kedua jenis bank tersebut dalam menjalankan kegiatan usahanya diklasifikasikan menjadi dua, yaitu bank konvensional dan bank dengan prinsip syariah (Undang-Undang Republik Indonesia Nomor 10 Tahun 1998, 1998).

Terbitnya Undang-Undang Nomor 10 tahun 1998, tentang Perubahan atas Undang-Undang Nomor 7 tahun 1992 tentang Perbankan, pada bulan November 1998 telah memberikan peluang yang sangat besar bagi tumbuhnya bank syariah maupun unit usaha syariah di Indonesia (Wirdyaningsih, K. P., Dewi, G., \& Barlinti, 2005). Seiring berjalannya waktu, Pemerintah Republik Indonesia menerbitkan UU Republik Indonesia Nomor 21 Tahun 2008 tentang Perbankan Syariah yang dikeluarkan pada tanggal 16 Juli tahun 2008 telah memberikan dasar hukum yang lebih memadai untuk perkembangan dunia industri perbankan syariah di Indonesia (Anshori, 2008).

Perbedaan mendasar antara bank konvensional dengan bank syariah adalah adanya larangan bunga dalam bank syariah sebagaimana sistem bunga yang dianut oleh bank konvensional. Sehingga dalam menjalankan kegiatan operasionalnya, bank syariah menganut sistem bagi hasil (profit sharing). (Yumanita, 2005). Keuntungan Bank syariah dari menerapkan sistem bagi hasil (profit sharing) dalam operasionalnya tidak hanyut oleh tingkat suku bunga simpanan yang melonjak sehingga beban operasional tetap stabil (M, Ali, \& Habbe, 2012) dan (Wulandari, 2004).

Pasal 7 UU Republik Indonesia Nomor 21 Tahun 2008, Bank Syariah adalah Bank yang menjalankan kegiatan usahanya berdasarkan Prinsip Syariah dan menurut jenisnya terdiri atas Bank Umum Syariah dan Bank Pembiayaan
Rakyat Syariah. Sementara itu dalam pasal 8 UU Republik Indonesia Nomor 21 Tahun 2008 menegaskan bahwa, Bank Umum Syariah adalah Bank Syariah yang dalam kegiatannya memberikan jasa dalam lalu lintas pembayaran (Undang-Undang Republik Indonesia Nomor 21 Tahun 2008, 2008).

Perkembangan Bank Umum Syariah di Indonesia sangat pesat dan berkembang baik walaupun berjalan dengan lambat. Hal ini terbukti dengan pertumbuhan aset tiap tahunnya. Tahun 2017 total aset Bank Umum Syariah di Indonesia sebesar Rp 288.027 miliar. Kemudian pada Desember 2018 total aset Bank Umum Syariah menjadi sebesar Rp 316.691 miliar. Dana pihak ketiga juga tumbuh 19.2 persen, dari Rp 238.393 miliar pada Desember 2017, menjadi Rp 257.606 miliar pada Desember 2018. Data bank umum syariah tersebut berdasarkan statistik perbankan syariah Desember 2018 (Otoritas Jasa Keuangan, 2019).

Profitabilitas merupakan kemampuan bank untuk menghasilkan atau memperoleh laba secara efektif dan efisien. Semakin besar (Return On Asset) ROA suatu bank, semakin besar tingkat keuntungan yang dicapai bank tersebut dan semakin baik pula kinerja bank tersebut dari segi penggunaan asset (Dendawijaya, 2005). Pentingnya ROA bagi bank, karena ROA digunakan untuk mengukur efektivitas perusahaan di dalam menghasilkan keuntungan dengan memanfaatkan aktiva yang dimilikinya. ROA merupakan rasio antara laba sesudah pajak terhadap total asset. Semakin besar ROA menunjukkan kinerja perusahaan semakin baik, karena tingkat kembalian (return) semakin besar (Husnan, 1998).

Penelitian tentang rasio keuangan dan pengaruhnya terhadap profitabilitas bank konvensional dan bank syariah di Indonesia telah dilakukan oleh beberapa peneliti dengan banyak perbedaan penelitian riset GAP. Penelitian serupa dilakukan (M et al., 2012), dalam penelitiannya menguji pengaruh rasio kesehatan bank terhadap keuangan bank umum syariah dan bank konvensional. Hasil penelitianya 
mengemukakan bahwa CAR dan Non Performing Finance (NPF) tidak berpengaruh signifikan terhadap ROA, BOPO berpengaruh negatif signifikan terhadap ROA, NOM berpengaruh positif signifikan terhadap ROA, FDR berpengaruh positif signifikan terhadap ROA pada Bank Umum Syariah di Indonesia. CAR berpengaruh positif signifikan terhadap ROA, BOPO tidak berpengaruh terhadap ROA, NIM berpengaruh positif signifikan terhadap ROA, NPL berpengaruh negatif dan signifikan terhadap ROA, LDR berpengaruh negatif signifikan terhadap ROA pada Bank Konvensional di Indonesia.

Hasil studi yang berkaitan dengan nonperforming loans (NPL) yang dilakukan oleh (Miller \& Noulas, 1997) membuktikan bahwa NPL berpengaruh secara negatif dan signifikan terhadap kinerja profitabilitas ROA perbankan nasional. Non Performing Loan (NPL) yang diteliti oleh (Limpaphayom \& Polwitoon, 2004), menunjukkan bahwa NPL berpengaruh positif terhadap ROA. Hasil penelitian (Limpaphayom \& Polwitoon, 2004) bertentangan dengan penelitian yang dilakukan oleh (Gelos, 2009) yang menunjukkan adanya pengaruh yang signifikan negatif NPL terhadap ROA.

Berdasarkan uraian di atas, tujuan penelitian ini adalah untuk mengetahui dan menganalisis pengaruh tingkat rasio kinerja industri bank umum syariah. Untuk mengetahui dan menganalisis pengaruh tingkat rasio kinerja diukur dengan Capital Adequacy Ratio (CAR), Biaya Operasional terhadap Pendapatan Operasional (BOPO), Financing to Deposit Ratio (FDR) dan Non Performing Finance (NPF) terhadap Profitabilitas (Return On Asset atau ROA) pada Industri Bank Umum Syariah di Indonesia.

Industri perbankan merupakan industri yang erat dengan risiko, terutama karena melibatkan pengelolaan uang masyarakat dan diputar dalam bentuk berbagai investasi, seperti pemberian kredit, pembelian surat-surat berhaga dan penanaman dana lainya (Ghozali, 2007). Industri perbankan sebagai sektor penting dalam pembangunan nasional yang berfungsi untuk financial intermediary diantara pihak-pihak yang memiliki kelebihan dana dengan pihak-pihak yang memerlukan dana. Faktor-faktor yang mempengaruhi profitabilitas bank dapat bersumber dari berbagai kinerja profitabilitas yang ditunjukkan beberapa indikator (Nasser \& Aryati, 2000).

\subsection{Profitabilitas (ROA)}

Profitabilitas atau yang juga biasa disebut dengan rentabilitas merupakan kemampuan perusahaan untuk menghasilkan laba selama periode laporan keuangan tertentu. Rentabilitas perusahaan menunjukkan perbandingan antara laba dengan aktiva atau modal yang menghasilkan laba tersebut (Riyanto, 2001). Selain itu ROA juga sebagai metode pengukuran yang obyektif yang didasarkan pada data akuntansi yang tersedia dan besarnya ROA dapat mencerminkan hasil dari serangkaian kebijakan perusahaan terutama pada perbankan (Riyanto, 1995).

ROA adalah salah satu rasio mengukur kemampuan bank menghasilkan keuntungan secara relatif dibandingkan dengan total assetnya atau ukuran untuk menilai seberapa besar tingkat pengembalian dari asset perusahaan (Santoso, 2000). Adapun rumus ROA berdasarkan ketentuan (Bank Indonesia, 2011) yang tercantum dalam Surat Edaran Bank Indonesia Nomor 13/30/DPNP tanggal 16 Desember 2011 sebagai berikut:

$$
R O A=\frac{\text { Laba Sebelum Pajak }}{\text { Rata }- \text { Rata Total Asset }} \times 100 \%
$$

\subsection{Biaya Operasional Per Pendapatan Operasional (BOPO)}

Biaya Operasional terhadap Pendapatan Operasional (BOPO) adalah rasio yang digunakan untuk mengukur efisiensi dan kemampuan manajemen bank dalam mengendalikan operasinya. Menurut adanya efisiensi pada perbankan terutama efisiensi biaya maka akan diperoleh tingkat keuntungan yang optimal, penambahan jumlah dana yang disalurkan, biaya lebih kompetitif, peningkatan 
pelayanan kepada nasabah, keamanan dan kesehatan perbankan yang meningkat (Kuncoro \& Suhardjono, 2002). Sementara itu menurut (Rivai, Veithzal, \& Idroes, 2007), BOPO merupakan perbandingan antara biaya operasional dengan pendapatan operasional dalam mengukur tingkat efisiensi dan kemampuan bank dalam melakukan kegiatan operasinya.

Rasio BOPO yang semakin kecil berarti menggambarkan biaya operasional yang dikeluarkan oleh bank tersebut semakin efisien, dan setiap peningkatan pendapatan operasional akan berakibat pada berkurangnya laba sebelum pajak yang pada akhirnya akan menurunkan laba atau profitabilitas (ROA) bank tersebut (Dendawijaya, 2005). BOPO diukur dengan membandingkan biaya operasional terhadap pendapatan operasional. Adapun rumus BOPO berdasarkan ketentuan (Bank Indonesia, 2011) sesuai Surat Edaran Bank Indonesia Nomor 13/30/DPNP tanggal 16 Desember 2011 sebagai berikut:

$$
B O P O=\frac{\text { Total Beban Operasional }}{\text { Total Pendapatan Operasional }} \times 100 \%
$$

\subsection{Financing To Deposit Ratio (FDR)}

(Simorangkir, 2004), menyatakan Loan to Deposit Ratio (LDR/FDR) merupakan perbandingan antara kredit yang diberikan dengan dana pihak ketiga, termasuk pinjaman yang diterima, tidak termasuk pinjaman subordinasi. Sedangkan menurut (Kasmir, 2008), Loan to Deposit Ratio yaitu Rasio yang digunakan untuk mengukur komposisi jumlah kredit yang diberikan dibandingkan dengan jumlah dana masyarakat dan modal sendiri yang digunakan. (Muhammad, 2005), menyatakan bahwa Financing to Deposit Ratio (FDR) merupakan perbandingan antara pembiayaan yang diberikan oleh bank dengan pihak ketiga yang berhasil diusahakan oleh bank. Berlandaskan ketentuan (Bank Indonesia, 2011) Surat Edaran Bank Indonesia Nomor 13/30/DPNP tanggal 16 Desember 2011 sebagai berikut dengan formula untuk mengukur FDR sebagai berikut:

$$
F D R=\frac{\text { Pembiayaan }}{\text { Dana Pihak ke Tiga }} \times 100 \%
$$

\subsection{Non Performing Finance (NPF)}

NPF digunakan untuk mengukur tingkat permasalahan pembiayaan yang dihadapi oleh bank syariah. Semakin besar NPF pada suatu bank berarti menandakan bahwa bank tersebut memiliki risiko pembiayaan yang ditanggung oleh bank. Sehingga semakin besar NPF suatu bank akan mengakibatkan profitabilitas (ROA) bank menjadi turun. Hal ini disebabkan oleh meningkatnya biaya yang dikeluarkan bank yaitu biaya pencadangan aktiva produktif yang dibutuhkan menjadi lebih tinggi (Rivai \& Arviyan, 2010). Begitu pula sebaliknya, jika Non Performing Financing (NPF) kecil, maka Profitabilitas akan semakin besar, sehingga kinerja keuangan bank dapat dikatakan semakin baik.

(Muhammad, 2005), Non Performing Financing (NPF) merupakan rasio yang menggambarkan kemampuan bank dalam mengelola kredit bermasalah yang telah disalurkan oleh bank kepada pihak ketiga, NPF dirumuskan dengan :

$$
N P F=\frac{\text { Jumlah Pembiayaan Bermasalah }}{\text { Total Pembiayaan }} \times 100 \%
$$

\subsection{Kerangaka Pemikiran Teoritis}

Penelitian ini akan menguji pengaruh CAR, BOPO, FDR dan NPF terhadap profitabilitas yang diproksi dengan Return on Asset (ROA). Berdasarkan teori dan hasil penelitian terdahulu yang telah diuraikan di atas, maka dapat dikembangkan kerangka pemikiran sebagai berikut :

\section{Gambar 1}

Kerangka Pemikiran

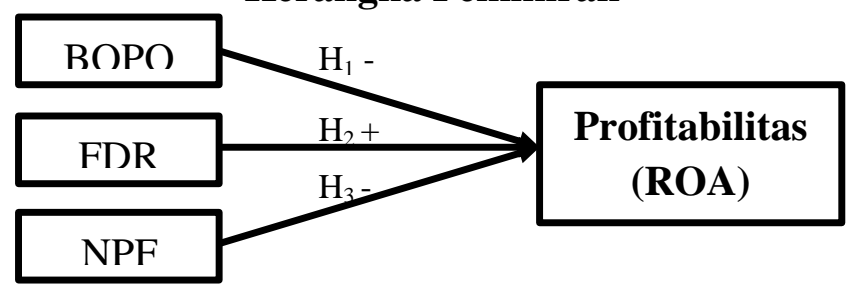



empat hipotesis yang dikembangkan dalam penelitian ini, empat hipotesis tersebut, yaitu :

Hipotesi 1 : BOPO berpengaruh negatif signifikan terhadap profitabilitas (ROA)

Hipotesi 2 : FDR berpengaruh positif signifikan terhadap profitabilitas (ROA)

Hipotesi 3 : NPF berpengaruh negatif signifikan terhadap profitabilitas (ROA)

\section{Metode Penelitian}

Penelitian ini merupakan penelitian kausatif dengan pendekatan kuantitatif. Penelitian ini menggunakan data sekunder, yaitu Biaya Operasional terhadap Pendapatan Operasional (BOPO), Financing to Deposit Ratio (FDR), Non Performing Finance (NPF) dan Profitabilitas (Return On Asset atau ROA) pada industri bank umum syariah yang terdaftar di Bank Indonesia. Data tersebut merupakan data time series bulanan dari tahun 2015 hingga 2018 yang diperoleh melalui situs resmi statistik perbankan syariah, Otoritas Jasa Keuangan (https://www.ojk.go.id). Untuk menganalisisnya, peneliti menggunakan model regresi linear berganda dengan software alat statistik EViews 9.
Sejalan dengan penjelasan teoritis, maka ada

Metode analisis yang digunakan untuk menguji hipotesi dalam penelitian ini adalah analisis regresi berganda, karena variabel bebas dalam penelitian ini lebih dari satu. Metode analisis regresi berganda merupakan teknik uji yang digunakan untuk mengetahui pengaruh variabel independen (BOPO, FDR dan NPF) terhadap variabel dependen (ROA). Formula persamaan analisis regresi berganda dapat dirumuskan sebagai berikut :

$R O A=\alpha+\beta_{1} B O P O_{1}+\beta_{2} F D R_{2}+\beta_{3} N P F_{3}+e \ldots . .(1)$

Keterangan :

ROA = Return On Asset .

$\mathrm{BOPO}=$ Biaya Operasional terhadap Pendapatan Operasional.

FDR = Financing to Deposit Ratio.

$\mathrm{NPF}=$ Non Performing Finance.

$\alpha=$ Konstanta.

$\beta 1,2,3=$ Koefisien Regresi.

e = Standar Error.

\section{Hasil dan Pembahasan}

Bedasarkan tujuan dari penelitian, yaitu untuk menganalisis pengaruh BOPO, FDR dan NPF terhadap Profitabilitas (ROA) Industri Bank Umum Syariah di Indonesia. Hasil model regresi linear berganda dalam penelitian dapat dilihat sebagai berikut:

Tabel 1

Hasil Analisis Regresi Linear Berganda Pengaruh BOPO, FDR dan NPF terhadap Profitabilitas (ROA) Industri Bank Umum Syariah di Indonesia

\begin{tabular}{rrrrr}
\hline \multicolumn{1}{c}{ Variable } & Coefficient & Std. Error & t-Statistic & Prob. \\
\hline ROA (Constant) & 10.63645 & 0.491708 & 21.63162 & 0.0000 \\
BOPO $\left(\mathrm{X}_{1}\right)$ & -0.115254 & 0.007807 & -14.76353 & 0.0000 \\
FDR $\left(\mathrm{X}_{2}\right)$ & 0.011641 & 0.004585 & 2.538880 & 0.0147 \\
NPF $\left(\mathrm{X}_{3}\right)$ & 0.007858 & 0.032627 & 0.240840 & 0.8108 \\
\hline R-squared & 0.930741 Durbin-Watson stat & & 1.518839 \\
Adjusted R-squared & 0.926019 & & \\
F-statistic & 197.0995 & & \\
Prob(F-statistic) & 0.000000 & & \\
\hline
\end{tabular}

Sumber : E-Views 9, diolah (2019)

$\mathrm{T}$ parsial ditunjukkan dengan nilai " $t$ Statistics". Nilai $\mathrm{p}$ value $\mathrm{t}$ parsial BOPO adalah 0,0000 dimana $<0,05$ sehingga menerima $\mathrm{H} 1$, yang berarti variabel BOPO berpengaruh secara parsial di dalam model terhadap variabel response (ROA). Nilai $\mathrm{p}$ value $\mathrm{t}$ parsial FDR adalah 0,0147 dimana $<0,05$ sehingga menerima H1, yang berarti variabel FDR berpengaruh secara parsial di dalam model terhadap variabel response (ROA). Nilai $\mathrm{p}$ value $\mathrm{t}$ parsial NPF 
adalah 0,8108 dimana > 0,05 sehingga menolak $\mathrm{H} 1$, yang berarti variabel NPF tidak singifikan secara parsial di dalam model terhadap variabel response (ROA). Koefisien beta adalah nilai prediksi sebuah variabel di dalam model terhadap variabel response. Nilai koefisien beta BOPO sebesar -0,115254, yang berarti BOPO dapat menjelaskan ROA sebesar $-11,5254 \%$ atau dapat diartikan: setiap perubahan satu satuan BOPO dapat mengakibatkan perubahan pada ROA sebesar $-11,5254 \%$. Nilai koefisien beta FDR sebesar 0,011641, yang berarti FDR dapat menjelaskan ROA sebesar $1,1641 \%$ atau dapat diartikan: setiap perubahan satu satuan FDR dapat mengakibatkan perubahan pada ROA sebesar $1,1641 \%$.

R-Squared atau nilai koefisien determinasi berganda sebesar 0.930741 yang berarti sekumpulan variabel prediktor di dalam model dapat menjelaskan variabel response sebesar 93,0741\%. Sedangkan sisanya dijelaskan oleh variabel lain di luar model yang diteliti. Nilai adjusted R-Square artinya nilai R-Square yang telah terkoreksi oleh nilai standar error. Nilai adjusted Rsquare sebesar 0.926019. Sedangkan nilai standar error model regresi 8,6832 ditunjukkan dengan label S.E. of regression. Nilai standar error ini lebih kecil dari pada nilai standar deviasi variabel response yang ditunjukkan dengan label "S.D. dependent var" yaitu sebesar 31,9241 yang dapat diartikan bahwa model regresi valid sebagai model prediktor.

Berdasarkan hasil regresi linear berganda pada tabel 1 diperoleh Biaya Operasional terhadap Pendapatan Operasional (BOPO) berpengaruh negatif signifikan terhadap ROA industri bank umum syariah di Indonesia. Hal ini dikarenakan nilai Prob. lebih kecil dari 0,05 yaitu sebesar 0,000 dan nilai koefisien beta BOPO sebesar -0.115254. Ini berarti variabel BOPO dalam hasil persamaan regresi berpengaruh dengan koefisien regresi negatif terhadap ROA industri bank umum syariah di Indonesia. Dengan demikian hipotesis pertama yang menyatakan BOPO berpengaruh negatif terhadap
ROA dapat diterima. Menurut (Dendawijaya, 2005), bank dalam mengukur tingkat efisiensi dan kemampuan kegiatan operasionalnya menggunakan rasio BOPO, semakin besar BOPO mengakibatkan semakin kecil laba yang diterima oleh bank, dengan begitu ROA bank menjadi turun. Sementara itu (Windriya, 2014), menyatakan nilai BOPO yang rendah menunjukan bahwa kegiatan operasional bank telah dilakukan secara efisien, sehingga dapat meningkatkan laba bank. Hasil penelitian ini senada dengan penelitian yang dilakukan ( $\mathrm{M}$ et al., 2012), bahwa BOPO berpengaruh negatif dan signifikan terhadap ROA pada Bank Umum Syariah. Nilai negatif BOPO menunjukkan bahwa semakin kecil BOPO semakin efisien bank dalam menjalankan aktifitas usahanya.

Tabel 1 menunjukkan pengaruh positif signifikan Financing to Deposit Ratio (FDR) terhadap ROA industri bank umum syariah di Indonesia. Hal ini dikarenakan nilai Prob. lebih kecil dari 0,05 yaitu sebesar 0,0147 dan nilai koefisien beta FDR sebesar 0,011641. Ini berarti variabel FDR dalam hasil persamaan regresi berpengaruh dengan koefisien positif terhadap ROA industri bank umum syariah di Indonesia. Dengan demikian hipotesis kedua yang menyatakan FDR berpengaruh positif terhadap ROA dapat diterima. Dari temuan penelitian ini diperkuat oleh (M et al., 2012), (Gelos, 2009), (Murdiyanto, 2018) dan (Nusantara, 2009), nilai koefisien positif FDR menunjukkan bahwa semakin tinggi kredit yang disalurkan menjadikan semakin besar ROA. Selanjutnya semakin banyak pembiayaan yang disalurkan bank umum syariah yang beroperasi di Indonesia akan memperoleh profitabilitas yang tinggi.

Hasil regresi linear berganda pada tabel 1 menunjukan bahwa Non Performing Financing (NPF) tidak berpengaruh positif signifikan terhadap ROA industri bank umum syariah di Indonesia. Hal ini dikarenakan nilai Prob. lebih besar dari 0,05 yaitu sebesar 0,8108 dan nilai koefisien beta NPF sebesar 0,007858. Hasil persamaan regresi dari variabel NPF mempunyai koefisien positif, maka dapat diartikan bahwa 
NPF tidak memiliki pengaruh terhadap ROA. Hal tersebut menjadikan hipotesis ketiga yang menyatakan NPF berpengaruh negatif terhadap ROA tidak dapat diterima. Dari temuan penelitian ini sejalan dengan hasil penelitian dari (Wardana \& Widyarti, 2015), menyatakan tinggi rendahnya NPF tidak terbukti mempengaruhi profitabilitas (ROA) Bank Umum Syariah. Menurut (Wibisono \& Wahyuni, 2017), NPF tidak berpengaruh signifikan terhadap ROA karena adanya variabel NOM (Net Operating Margin) sebagai memediasi pengaruh antara NPF dengan ROA.

\section{Kesimpulan}

Dari tiga variabel independen (BOPO, FDR dan NPF) menunjukan bahwa BOPO paling besar pengaruhnya terhadap ROA dengan nilai beta yang paling tinggi dibanding kedua variabel lainya yaitu sebesar -0.115254, sedangkan variabel NPF tidak signifikan. Maka dapat diartikan bahwa BOPO sangat berpengaruh signifikan negatif terhadap profitabilitas. Untuk meningkatkan profitabilitas disarankan bagi manajemen bank lebih menjaga rasio internal bank, khususnya industri Bank Umum Syariah di Indonesia. Penting bagi Manajemen Bank Umum Syariah dalam mengelola rasio BOPO untuk menjaga tingkat efisiensi bank dan meningkatkan kinerja perusahaan sehingga profitabilitas perusahaan dapat meningkat.

Financing to Deposit Ratio (FDR) berpengaruh positif signifikan terhadap profitabilitas industri bank umum syariah di Indonesia yang diproksikan dengan ROA. Nilai signifikansi pada probabilitas lebih kecil dari 0,05 yaitu sebesar 0,0147 dan nilai koefisien beta FDR sebesar 0,011641. Hal tersebut menunjukan variabel FDR secara parsial berpengaruh positif signifikan terhadap profitabilitas (ROA). Oleh sebab itu tinggi rendahnya FDR terbukti dapat mempengaruhi ROA. Di sarankan bagi Manajemen Bank Umum Syariah dalam meningkatkan dan mengelola dana pihak ketiga dalam bentuk loan/financing sehingga profitabilitas perusahaan dapat meningkat.

\section{Ucapan Terimakasih}

Kami selaku penulis dengan sepenuh hati menyampaikan terima kasih kepada seluruh pihak yang sudah memberikan dukungan dan do'a sehingga penulis dapat menyelesaikan penelitian ini, khususnya kepada LPPM STIE AAS Surakarta yang sudah membantu dan mendukung dari awal hingga akhir selesainya penelitian ini.

\section{Daftar Pustaka}

Anshori, A. G. (2008). Sejarah Perkembangan Hukum Perbankan Syariah di Indonesia dan Implikasinya bagi Praktik Perbankan Nasional. La_Riba, II(Desember), 159. https://doi.org/10.20885/lariba.vol2.iss2.art1

Bank Indonesia. SURAT EDARAN BANK INDONESIA NOMOR 13/30/DPNP TANGGAL 16 DESEMBER 2011., Pub. L. No. No. 3/30/DPNP (2011).

Dendawijaya, L. (2005). Manajemen perbankan (2nd ed.). Bogor: Ghalia Indonesia.

Gelos, R. G. (2009). Banking spreads in Latin America. Economic Inquiry, 47(Oktober), 796-814. https://doi.org/10.1111/j.14657295.2008.00144.x

Ghozali, I. (2007). Manajemen Risiko Perbankan Pendekatan Value at Risk (VaR). Semarang: Badan Penerbit Universitas Diponegoro.

Husnan, S. (1998). Dasar - dasar Teori Portofolio dan Analisis Sekuritas (3rd ed.). Yogyakarta: UPP AMP YKPN.

Kasmir. (2008). Manajemen Perbankan. Jakarta: Rajagrafindo Persada.

Kuncoro, M., \& Suhardjono. (2002). Manajemen perbankan teori dan aplikasinya. Yogyakarta: BPFE.

Limpaphayom, P., \& Polwitoon, S. (2004). Bank relationship and firm performance: Evidence from Thailand before the Asian financial crisis. Journal of Business Finance and Accounting. https://doi.org/10.1111/j.0306686X.2004.00585.x

M, M. S., Ali, M., \& Habbe, A. H. (2012). Pengaruh rasio kesehatan bank terhadap kinerja keuangan bank umum syariah dan bank konvensional di indonesia. Jurnal Analisis, 1(Juni). Retrieved from http://pasca.unhas.ac.id/jurnal/files/870a91e b9495ed13bfe071e5bf00154a.pdf 
Miller, S. M., \& Noulas, A. G. (1997). Portfolio mix and large-bank profitability in the USA. Applied Economics. https://doi.org/10.1080/000368497326994

Muhammad. (2005). Manajemen Bank Syariah. Yogyakarta: UPP AMP YKPN.

Murdiyanto, A. (2018). Faktor-Faktor yang Berpengaruh terhadap ROA (Studi Pada Bank Umum Syariah di Indonesia Periode Tahun 2012-2017). Prosiding SENDI_U. Retrieved from https://www.unisbank.ac.id/ojs/index.php/se ndi_u/article/view/6046/1912

Nasser, E. M., \& Aryati, T. (2000). Model analisis CAMEL untuk memprediksi financial distress pada sektor perbankan yang go public. Indonesian Journal of Accounting and Auditing, 4(Desember), 111-130. Retrieved from https://journal.uii.ac.id/JAAI/article/view/11 298/8637

Nusantara, A. B. (2009). Analisis Pengaruh NPL, CAR, LDR, dan BOPO Terhadap Profitabilitas Bank (Universitas Diponegoro). Retrieved from http://eprints.undip.ac.id/16298/1/Ahmad_B uyung_Nusantara.pdf

Otoritas Jasa Keuangan, R. I. (2019, February). Statistik Perbankan Syariah (SPS). Departemen Perizinan Dan Informasi Perbankan. Retrieved from https://www.ojk.go.id/id/kanal/syariah/datadan-statistik/statistik-perbankansyariah/Documents/Pages/StatistikPerbankan-Syariah---Desember-2018/SPS Desember 2018.pdf

Rivai, V., \& Arviyan, A. (2010). Islamic Banking Sebuah Teori, Konsep, dan Aplikasi. Jakarta: Bumi Aksara.

Rivai, V., Veithzal, A. P., \& Idroes, F. N. (2007). Bank and Financial Institution Mangement. Jakarta: Raja Grafindo Persada.

Riyanto, B. (1995). Dasar-Dasar Pembelanjaan Perusahaan. Yogyakarta: BPFE.

Riyanto, B. (2001). Dasar-dasar Pembelanjaan Perusahaan (4th ed.). Yogyakarta: BPFE.

Santoso, R. T. (2000). Prinsip Dasar Akuntansi Perbankan. Yogyakarta: Andi Offset.

Simorangkir, O. P. (2004). Pengantar Lembaga Keungan Bank dan Non Bank. Bogor: Ghalia Indonesia.
Undang-Undang Republik Indonesia Nomor 10 Tahun 1998. Undang-Undang Republik Indonesia Nomor 10 Tahun 1998 Tentang Perubahan Atas Undang-Undang Nomor 7 Tahun 1992. , (1998).

Undang-Undang Republik Indonesia Nomor 21 Tahun 2008. Undang-Undang Republik Indonesia Nomor 21 Tahun 2008 Tentang Perbankan Syariah. , (2008).

Wardana, R. I. P., \& Widyarti, E. T. (2015). Analisis Pengaruh CAR, FDR, NPF, BOPO, dan SIZE terhadap Profitabilitas pada Bank Umum Syariah di Indonesia (Studi Kasus pada Bank Umum Syariah di Indonesia Periode 2011-2014). Diponegoro Journal Of Management, Volume 4 N, 1-11. Retrieved from

http://eprints.undip.ac.id/46570/1/07_WAR DANA.pdf

Wibisono, M. Y., \& Wahyuni, S. (2017). Pengaruh CAR, NPF, BOPO, FDR, terhadap ROA yang Dimediasi oleh NOM. Jurnal Bisnis Dan Manajemen, 17, 41-62. https://doi.org/https://doi.org/10.20961/jbm. v17i1.12304

Windriya, A. (2014). Analisis Pengaruh Faktor Eksternal dan Faktor Internal Bank Terhadap Profitabilitas Bank Umum Syariah Indonesia (Periode 2008-2013) (Universitas Diponegoro). Retrieved from http://eprints.undip.ac.id/43555/1/13_WIND RIYA.pdf

Wirdyaningsih, K. P., Dewi, G., \& Barlinti, D. Y (2005). Bank dan Asuransi Islam di Indonesia. Jakarta: Kencana.

Wulandari, N. (2004, November 22). Keunggulan Komparatif Bank Syariah. Suara Merdeka.

Yumanita, A. D. (2005). Bank Syariah: Gambaran Umum. Retrieved from https://www.bi.go.id/id/publikasi/serikebanksentralan/Documents/14. Bank Syariah Gambaran Umum.pdf 